\title{
Runoff and Nutrient Losses from Constructed Soils Amended with Compost
}

\author{
N. E. Hansen, ${ }^{1}$ D. M. Vietor, ${ }^{2}$ C. L. Munster, ${ }^{3}$ R. H. White, ${ }^{2}$ and T. L. Provin ${ }^{2}$ \\ ${ }^{1}$ Agricultural Technical Institute, The Ohio State University, 1328 Dover Rd., Wooster, OH 44691, USA \\ ${ }^{2}$ Soil and Crop Sciences Department, Texas A\&M University, 2474 TAMU, College Station, TX 77843-2474, USA \\ ${ }^{3}$ Department of Biological and Agricultural Engineering, Texas A\&M University, 2117 TAMU, College Station, TX 77843-2117, USA
}

Correspondence should be addressed to N. E. Hansen, hansen.209@osu.edu

Received 13 October 2011; Accepted 15 January 2012

Academic Editor: Leonid Perelomov

Copyright (C 2012 N. E. Hansen et al. This is an open access article distributed under the Creative Commons Attribution License, which permits unrestricted use, distribution, and reproduction in any medium, provided the original work is properly cited.

\begin{abstract}
Composted organic materials used to stabilize roadside embankments in Texas promote rapid revegetation of soils disturbed by construction activities. Yet, adding compost to soil may increase total and soluble plant nutrients available for loss in runoff water. Composted municipal biosolids and dairy manure products were applied to soils in Texas according to prescribed Texas Department of Transportation specifications for stabilizing roadside soils. The specifications included a method for incorporating compost into soils prior to seeding or applying a compost and woodchip mix over a disturbed soil and then seeding. Applying compost and woodchips over the soil surface limited sediment losses (14 to 32 fold decrease) compared to incorporating compost into the soil. Yet, the greatest total phosphorus and nitrogen losses in runoff water occurred from soils where the compost and woodchip mix was applied. The greatest losses of soluble phosphorus also occurred when the compost and woodchip mix was applied. In contrast, nitrate-nitrogen losses in runoff were similar when compost was incorporated in the soil or applied in the woodchip mix. Compost source affected the nutrient losses in runoff. While the composted municipal biosolids added greater nutrient loads to the soil, less nutrient loss in runoff occurred.
\end{abstract}

\section{Introduction}

State Departments of Transportation (SDOT) are mandated to manage highway construction sites as potential nonpoint pollution sources. Soil particulate loads are often the greatest fraction of soil components in runoff from highway construction sites [1]. Soil erosion can occur when disturbed soils are unprotected from rainfall and flowing water. Silt fences, straw mulch, and material blankets are among several practices used to control erosion [2]. Additionally, composted biosolids and blends of biosolids with yard waste are among materials top-dressed or incorporated on constructed soil slopes to control erosion and enhance vegetation establishment [3-5]. Persyn et al. [5] reported 5 or $10 \mathrm{~cm}$ blankets of composted biosolids, yard waste, or industrial waste reduced runoff water and sediment compared to exposed subsoil or imported topsoil to high-way construction sites. In a complementary report, Glanville et al. [3] reported top-dressing composted materials decreased nutrient loss in runoff water during a simulated $30 \mathrm{~min}$ rain event compared to excavated soil alone.

Specifications for the composition and application of composted materials to soil on construction sites vary among SDOTs [6]. Generally, application rates are depth- or volume-based and include limits on the maximum rate which can be applied. Composted materials are required to meet standards for Class A biosolid, but requirements or limits on mineral nutrient concentrations or rates in applied materials are not often specified [7]. Large volume-based rates may have the potential to increase total nutrient concentrations in amended soil above requirements for establishment and maintenance of vegetation and contribute to nonpoint source losses in surface runoff [8].

In Texas, the Department of Transportation (TxDOT) developed three specifications for top-dressed and incorporated amendments on high-way construction sites. A topdressed layer of compost on excavated soil, termed erosion control compost (ECC), is comprised of a $5 \mathrm{~cm}$ depth of 
a blend of equal volumes of compost and woodchips [7]. Top dressing of a $0.6 \mathrm{~cm}$ depth of $100 \%$ compost on existing vegetation was defined as general use compost. In contrast to top-dressed treatments, compost-manufactured topsoil (CMT) was composed of a mixture of $0.25 \mathrm{~m}^{3}$ compost $\mathrm{m}^{-3}$ soil. The compost is incorporated with soil on-site or premixed and applied at a depth specified by engineers after excavation of a site.

The CMT and ECC specifications were developed to enable construction contractors a method to control sediment loss in runoff water and minimize the duration of vegetation reestablishment. Both composted dairy manure $(\mathrm{CDM})$ and blends of municipal biosolids and yard waste $(\mathrm{CMB})$ were among materials construction contractors used to comply with the TxDOT specifications [9]. Systems integrating compostuse with soil stabilization of roadsides offer an option for recycling composts, but total nutrient rates can exceed agronomic recommendations for crops or establishing vegetation [10]. Specifications for volume-based rates typically do not change with respect to compost source and composition.

Similar to concerns about CDM applications to agricultural fields, volume-based rates specified of ECC or CMT could increase soil nutrient concentrations and contribute to nonpoint-source runoff losses. Previous reports indicated runoff concentrations and losses of dissolved $\mathrm{P}$ were directly related to concentrations in top-dressed amendments [11, 12]. Incorporation of $\mathrm{CDM}$ or $\mathrm{CMB}$ at volume-based rates increased concentrations of extractable soil $\mathrm{P}$ and dissolved $P$ in runoff [13-15]. Variation of nutrient concentration and form among composted materials, including CDM and $\mathrm{CMB}$, and amended soils needs to be evaluated in relation to nonpoint-source losses $[12,16]$. In some cases, manure applications increase dissolved $\mathrm{P}$ loss more than inorganic fertilizers [17, 18]. Yet a dense layer of crop residues or established vegetation on amended surfaces can limit runoff loss of $\mathrm{P}$ from applied manure or compost $[18,19]$.

The goal of this research was to evaluate TxDOT specifications for amending roadside soils with CDM and CMB. The specific objectives were (1) quantify nutrient loading rates in soil amended according to CMT and ECC specifications, (2) compare runoff concentration and losses of sediment $\mathrm{P}$ and $\mathrm{N}$ among CMT and ECC treatments during natural storm events, and (3) relate P loss in runoff water to soil $\mathrm{P}$ concentrations.

\section{Materials and Methods}

2.1. Experimental Design. A randomized complete block design was comprised of three replications of seven treatments to compare and contrast treatment effects. Six treatments represented TxDOT specifications for application of CDM or $\mathrm{CMB}$ on roadsides [7]. Compost sources were incorporated at a rate of 0.125 and $0.25 \mathrm{~m}^{3} \mathrm{~m}^{-3}$ into a $50 \mathrm{~mm}$ depth of a sandy clay loam soil (Table 1) for four CMT treatments. A compost/woodchip blend $(1: 1)$ utilizing both compost sources was top-dressed onto an excavated soil for two ECC treatments. An established stand of common bermudagrass (Cynodon dactylon L.) was used as the one control treatment.
TABLE 1: Characteristics of two compost sources used to amend soils according to TxDOT specifications for stabilizing soils affected by highway construction ( $n=2$ for each compost source).

\begin{tabular}{lccc}
\hline & $\mathrm{N}(\%)$ & $\mathrm{P}(\%)$ & Dry mass $(\%)$ \\
\hline Composted dairy manure & 0.54 & 0.32 & 77.2 \\
Composted municipal biosolids & 1.73 & 1.66 & 65.5 \\
\hline
\end{tabular}

Treatments were imposed on a Boonville fine sandy loam previously graded to an $8.5 \%$ slope $[18,20]$. The excavated slope was located at the Texas A\&M University Turfgrass Field Laboratory, College Station, TX. The $4 \mathrm{~m}$ by $1.5 \mathrm{~m}$ plots were oriented parallel to the slope. A $100 \mathrm{~mm}$ width of $1.9 \mathrm{~mm}$ sheet metal was inserted $25 \mathrm{~mm}$ into soil along the perimeter of each plot to channel runoff through an $\mathrm{H}$-flume into an uncovered $311 \mathrm{~L}$ holding tank.

The compost products used in the study are characterized in Table 1. Both products were aerobically composted and produced in Texas. The mass of soil and compost or woodchips and compost mixes were measured, and sampled prior to application (Table 2). A seed mixture of $50 \mathrm{~g}$ common bermudagrass and $70 \mathrm{~g}$ T-587 Bluestem (Andropogon gerardii, Vitman) was broadcast over each plot area on 22 April 2003. The soil and compost and the woodchip and compost mixes were smoothed and packed to optimize seed to soil contact. The plots were irrigated daily to minimize water stress during seed germination and establishment. Care was taken to not produce runoff when irrigation water was applied. The bluestem/bermudagrass mixture was clipped on 26 June and 29 July. The mass of freshly clipped grass was measured and samples were collected to measure dry matter yields. Soil core samples were collected after the final rain event. A $20 \mathrm{~mm}$ diameter soil probe was used to sample soil to a $50 \mathrm{~mm}$ depth at eight randomly selected points within each plot. Soil cores were homogenized for each plot and prepared for analysis.

2.2. Runoff Sampling and Analysis. Captured runoff was measured and sampled after each of 10 natural rainfall events that produced measurable runoff from all plots. Rain depth was measured using an onsite rain gauge. Rainfall depth was subtracted from water depths in the uncovered tanks before runoff volumes were calculated. Tank volumes were mixed thoroughly before collecting $500 \mathrm{~mL}$ samples at the conclusion of rainfall events or before tanks overflowed. After collection, water samples were stored at $4^{\circ} \mathrm{C}$ and filtered through glass fiber filters $(<0.7 \mu \mathrm{m})$ under vacuum within a $24 \mathrm{hr}$ period. Samples were frozen if stored for more than $24 \mathrm{hr}$ before filtering. The mass of the sediment was calculated by subtracting the filter mass from the filter plus sediment mass after filtering was complete. Filters and sediment were ground and digested for analysis of total $\mathrm{N}$ and $\mathrm{P}$ after selected rain events [21].

Total and dissolved forms of $\mathrm{P}$ and $\mathrm{N}$ in the filtrate were analyzed for all runoff events. Inductively coupled plasma optical emission spectroscopy (ICP) was used to measure total TDP in digests of filtrate and total P (TP) in digests of sediment [22]. Total Kjeldahl nitrogen (TKN) in digests 
TABLE 2: Effect of rates of compost and associated total N (TN) and P (TP) on TN, TP, soil-test P (STP), and water-extractable P (WEP) concentrations in soil on an $8.5 \%$ slope. Composted dairy manure (CDM) and municipal biosolids (CMB) were incorporated at volumebased rates in compost-manufactured topsoil (CMT) or mixed with wood chips in erosion-control compost (ECC) as specified by the Texas Department of Transportation. The control was established perennial grass.

\begin{tabular}{|c|c|c|c|c|c|c|c|c|c|c|c|c|c|c|c|c|}
\hline \multirow{3}{*}{$\begin{array}{l}\text { Treatment } \\
\text { Control }\end{array}$} & \multirow{3}{*}{$\begin{array}{c}\text { Compost } \\
\text { NA }\end{array}$} & \multirow{3}{*}{$\frac{\begin{array}{c}\text { Rate } \\
\left(\mathrm{m}^{3} \mathrm{~m}^{-3}\right)\end{array}}{\mathrm{NA}}$} & \multicolumn{6}{|c|}{ Rates applied as compost } & \multicolumn{8}{|c|}{ Concentration within $5 \mathrm{~cm}$ sampling depth } \\
\hline & & & \multicolumn{2}{|c|}{$\begin{array}{c}\text { Mass } \\
\left(\mathrm{Mgha}^{-1}\right)\end{array}$} & \multicolumn{2}{|c|}{$\begin{array}{c}\mathrm{TP} \\
\left(\mathrm{kg} \mathrm{ha}^{-1}\right)\end{array}$} & \multicolumn{2}{|c|}{$\begin{array}{c}\mathrm{TN} \\
\left(\mathrm{kg} \mathrm{ha}^{-1}\right)\end{array}$} & \multicolumn{2}{|c|}{$\begin{array}{c}\mathrm{TP} \\
\left(\mathrm{mg} \mathrm{kg}^{-1}\right)\end{array}$} & \multicolumn{2}{|c|}{$\begin{array}{c}\mathrm{TN} \\
\left(\mathrm{mg} \mathrm{kg}^{-1}\right)\end{array}$} & \multicolumn{2}{|c|}{$\begin{array}{c}\mathrm{STP} \\
\left(\mathrm{mg} \mathrm{kg}^{-1}\right)\end{array}$} & \multicolumn{2}{|c|}{$\begin{array}{c}\text { WEP } \\
\left(\mathrm{mg} \mathrm{kg}^{-1}\right)\end{array}$} \\
\hline & & & & & & & & & 254 & $\mathrm{e}$ & 1188 & $\mathrm{~cd}$ & 80 & $\mathrm{e}$ & 17 & $\mathrm{~d}$ \\
\hline CMT & CDM & 0.125 & 62 & $\mathrm{~d}^{\ddagger}$ & 199 & $\mathrm{f}$ & 320 & $\mathrm{f}$ & 537 & de & 725 & $\mathrm{e}$ & 264 & de & 34 & $\mathrm{~cd}$ \\
\hline CMT & $\mathrm{CMB}$ & 0.125 & 28 & $\mathrm{f}$ & 408 & $\mathrm{~d}$ & 468 & e & 875 & $\mathrm{~cd}$ & 1035 & de & 439 & $\mathrm{~cd}$ & 29 & $\mathrm{~d}$ \\
\hline CMT & $\mathrm{CDM}$ & 0.25 & 109 & $\mathrm{~b}$ & 337 & e & 566 & $\mathrm{~d}$ & 761 & $\mathrm{~d}$ & 1059 & de & 496 & $\mathrm{~cd}$ & 50 & $\mathrm{bc}$ \\
\hline CMT & $\mathrm{CMB}$ & 0.25 & 50 & e & 810 & $\mathrm{~b}$ & 865 & $c$ & 1201 & $c$ & 1515 & $c$ & 623 & $c$ & 33 & $\mathrm{~cd}$ \\
\hline ECC & $\mathrm{CDM}$ & 0.50 & 185 & $\mathrm{a}$ & 611 & c & 944 & b & 1773 & $\mathrm{~b}$ & 2759 & b & 1115 & b & 77 & $\mathrm{a}$ \\
\hline ECC & $\mathrm{CMB}$ & 0.50 & 100 & c & 1773 & $\mathrm{a}$ & 1712 & $\mathrm{a}$ & 5121 & $\mathrm{a}$ & 5212 & $\mathrm{a}$ & 2203 & $\mathrm{a}$ & 55 & $\mathrm{~b}$ \\
\hline
\end{tabular}

${ }^{\dagger}$ Different letters in columns represent significant differences using Fisher's LSD means separation test.

of filtrate and sediment were measured colorimetrically $[23,24]$, and $\mathrm{NO}_{3}{ }^{-}-\mathrm{N}$ in filtrate was quantified through cadmium reduction in an autoanalyzer [25]. As filtrate concentrations of TKN dropped below $10 \mathrm{mg} \mathrm{L}^{-1}$, Kjeldahl digestions of filtrate were discontinued and the ICP was used to measure TDP in filtrate. Nutrient concentrations in filtrate were adjusted to account for dilution from rainfall in the uncovered tanks. A malachite-green assay was used to quantify dissolved reactive phosphorus (DRP) concentrations in filtrate within $72 \mathrm{hr}$ after filtering and storage at $4^{\circ} \mathrm{C}$ [26].

Concentrations of total and extractable forms of $\mathrm{P}$ and $\mathrm{N}$ in soil samples were analyzed in Texas AgriLife Extension's Soil, Water, and Forage Testing Laboratory, College Station, TX. An acidified $\mathrm{NH}_{4} \mathrm{OAc}-\mathrm{EDTA}$ extraction method was used to measure soil-test P (STP) [27]. In addition, $1 \mathrm{~g}$ soil was extracted in $10 \mathrm{~mL}$ distilled water for $1 \mathrm{hr}$ on an orbital shaker to determine water extractable $\mathrm{P}$ concentration. The ICP was used to measure STP and WEP. Soil nitrate was extracted and analyzed as described by Dorich and Nelson [23].

2.3. Statistical Analysis. The General Linear Model (GLM) procedure of SAS [28] was used for analysis of variance of runoff depth, nutrient concentration in soil and runoff, and mass loss of sediment and nutrients among treatments over ten runoff events. Fisher's least significant difference (LSD) was used to compare treatment means [28]. Treatment means were determined to be significantly different at the $\alpha=0.05$ level. Regression analysis was used to relate variation of total and extractable P within CMT and ECC to mass loss in runoff over 10 runoff events during grass establishment. A $t$-test was performed to detect significant differences between CMB sources by comparing the slopes of the regression lines [29].

\section{Results and Discussion}

3.1. Soil. The mass of the compost and soil or woodchip mixes was different due to the differences in bulk density of the compost sources. The bulk density of CDM was $1.34 \mathrm{Mg} \mathrm{m}^{-3}$, and the bulk density of CMB was $0.79 \mathrm{Mg} \mathrm{m}^{-3}$ which contributed to a greater mass of CDM than CMT in the volume-based rates applied as CMT and ECC (Table 2). The comparatively greater bulk density of CDM was attributed to soil scraped and hauled with raw manure from confined animal dry lots [30]. Yet the physical difference in mass did not translate into greater nutrient loading from the $\mathrm{CDM}$ since the nutrient concentrations were lower relative to $\mathrm{CMB}$ (Table 1). For each treatment with contrasting compost sources and application rates, the TP applied was over two times greater for the CMB than the CDM (Table 2). The TN application rate was also greater when $\mathrm{CMB}$ was used to amend soils rather than CDM (Table 2). In general, adding $\mathrm{CDM}$ or $\mathrm{CMB}$ as a soil amendment increased total P and N, STP, and WEP compared to the control. However, applying CDM at $0.125 \mathrm{~m}^{3} \mathrm{~m}^{-3}$ did not increase the nutrient concentration above the control for any soil nutrient characteristic tested (Table 2). Additionally, nutrient concentrations in the blended soil or woodchip mixes at the $0.125 \mathrm{~m}^{3} \mathrm{~m}^{-3}$ rate were not considered different between contrasting compost sources. Soil nutrient concentrations in the surface $50 \mathrm{~mm}$ layer were different for TP and TN when compost was blended at the $0.25 \mathrm{~m}^{3} \mathrm{~m}^{-3}$ volume-based rate. A large difference in concentration of soil nutrients became apparent when the compost sources were blended with woodchips for the ECC treatment. Total P and STP concentrations were nearly twice as great when $\mathrm{CMB}$ was used in the blend rather than CDM. The concentration of STP exceeded the concentration required to supply sufficient $\mathrm{P}$ for grass growth for each treatment included in the soil of the control plots. Grass plants used for turf are not expected to increase yield due to added P when STP concentrations are greater than $45 \mathrm{mg} \mathrm{kg}^{-1}$ [31]. Increasing STP concentrations relative to the critical concentration for plant response may relate to elevated $\mathrm{P}$ in runoff [32].

3.2. Grass Response. Bluestem seedlings emerged quickly and composed most of the biomass clipped from all treatments on two harvest dates. At $63 \mathrm{~d}$ after seeding, dry biomass yields 
TABLE 3: Above-ground dry-mass yield $\left(\mathrm{g} \mathrm{m}^{-2}\right)$ of a bermudagrass, Cynodon dactylon L., and big bluestem, Andropogon gerardii, Vitman grass mix grown on soils amended with composted dairy manure (CDM) or composted municipal biosolids (CMB) using TxDOT specifications for stabilizing soils affected by highway construction. See Table 2 caption for description of treatments.

\begin{tabular}{lcccccc}
\hline Treatment & Compost & $\begin{array}{c}\text { Rate } \\
\left(\mathrm{m}^{3} \mathrm{~m}^{-3}\right)\end{array}$ & $\begin{array}{c}\text { 1st harvest } \\
\left(\mathrm{g} \mathrm{m}^{-2}\right)\end{array}$ & $\begin{array}{c}\text { 2nd harvest } \\
\left(\mathrm{g} \mathrm{m}^{-2}\right)\end{array}$ \\
\hline Control & NA & NA & 35 & $\mathrm{c}$ & 58 & $\mathrm{c}$ \\
CMT & CDM & 0.125 & 56 & $\mathrm{bc}$ & 244 & $\mathrm{ab}$ \\
CMT & CMB & 0.125 & 103 & $\mathrm{abc}$ & 272 & $\mathrm{ab}$ \\
CMT & CDM & 0.25 & 42 & $\mathrm{bc}$ & 284 & $\mathrm{ab}$ \\
CMT & CMB & 0.25 & 113 & $\mathrm{abc}$ & 211 & $\mathrm{bc}$ \\
ECC & CDM & 0.50 & 184 & $\mathrm{a}$ & 215 & $\mathrm{bc}$ \\
ECC & CMB & 0.50 & 130 & $\mathrm{ab}$ & 382 & $\mathrm{a}$ \\
\hline
\end{tabular}

${ }^{\dagger}$ Different letters in columns represent significant differences using Fisher's LSD means separation test.

were similar between the established grass control and CMT comprising either CDM or CMB (Table 3). In contrast, the yield of dry biomass was greater for ECC composed of either $\mathrm{CDM}$ or $\mathrm{CMB}$ than for the established grass control. At $98 \mathrm{~d}$ after seeding, comparative biomass yields between the control and CMT were dependent on the compost source. Clipping yields of CMT amended with CDM were greater than the control for both of the volume-based rates $(0.125$ and $0.25 \mathrm{~m}^{3} \mathrm{~m}^{-3}$ ). Similarly, clipping yields from the CMT composed of $0.125 \mathrm{~m}^{3} \mathrm{CMB} \mathrm{m} \mathrm{m}^{-3}$ soil were greater than the established grass control, but yields were comparable between the higher $\mathrm{CMB}$ rate and control. In addition, yields were similar between ECC amended with either CDM or $\mathrm{CMB}$ and the established grass control on the second harvest. Developing deficiencies of available $\mathrm{N}$ or other mineral nutrients could have limited grass growth and differences in biomass yield between ECC and the established grass control at the second harvest date [33].

In a previous study of grass establishment after mixing $\mathrm{CMB}$ with soil at $0.25 \mathrm{~m}^{3} \mathrm{~m}^{-3}$, grass coverage was $14 \%$ greater with compared to without a top-dressing of fertilizer $\mathrm{N}\left(50 \mathrm{~kg} \mathrm{ha}^{-1}\right)$ at $56 \mathrm{~d}$ after sprigging [34]. Over a similar phase of wheat (Triticum aestivum L.) establishment, $\mathrm{N}$ deficiency symptoms and reduced dry matter production occurred for soil with up to $44 \mathrm{Mg} \mathrm{ha}^{-1} \mathrm{CMB}$ compared to fertilized soil without CMB [33]. Wheat establishment was deterred even though $100 \mathrm{mg} \mathrm{kg}^{-1}$ of fertilizer $\mathrm{N}$ was applied to supplement the total $\mathrm{N}$ applied as $\mathrm{CMB}$. Incubation studies with and without $\mathrm{CMB}$ in the same study indicated $\mathrm{N}$ immobilization could limit availability to crops established in soils amended with $\mathrm{CMB}$ at rates comparable to the CMT and ECC in the present study.

3.3. Runoff Loss of Sediment and Total $N$ and $P$. The cumulative depth of rainfall for the ten recorded events was $281 \mathrm{~mm}$. Total runoff loss for the ten events ranged between $137 \mathrm{~mm}$ for the ECC using CMB to $206 \mathrm{~mm}$ for the $0.25 \mathrm{~m}^{3} \mathrm{~m}^{-3} \mathrm{CMT}$ using the CDM (Table 4). Only the runoff loss from the latter treatment was greater than runoff loss from the established grass control. Generally, each specification for amending constructed soils was equally effective at controlling runoff water loss; however, compost source did result in differences in runoff. Runoff water losses were lower when CMB was incorporated into soil or mixed with woodchips and topdressed. The difference was most apparent for the ECCtreated plots (Table 4). The variation of runoff depth among treatments under the 10 natural rain events was substantially less than observed previously under $30 \mathrm{~min}$ of simulated rain. Persyn et al. [5] reported that 50 or $100 \mathrm{~mm}$ depths of biosolids mixed with yard waste achieved major delays and volume reductions in runoff compared to exposed subsoil under the brief simulated rain event.

Similar to evaluations of ECC comprising a $3: 1$ mixture of CDM and wood chips [10], sediment loss from ECC in the present study was comparable to established perennial grass (Table 4). On a 33\% roadside embankment without vegetation, a 50 or $100 \mathrm{~mm}$ depth of biosolids mixed with yard waste reduced interrill erosion $77 \%$ compared to exposed subsoil [35]. Seeding and establishment of vegetation reduced interrill erosion from the $33 \%$ slope, but erosion remained $70 \%$ less for biosolid mixed with yard waste than for exposed subsoil. Over the period of grass establishment in the present study, incorporation of CDM or CMB in soil controlled sediment loss less effectively than ECC. In addition, sediment loss from CMT amended with $0.25 \mathrm{~m}^{3} \mathrm{~m}^{-3}$ of compost was greater for CDM than for CMB (Table 4). As the greater weight of applied CDM indicated (Table 1), soil made up a larger portion of CDM than CMB, which could have diminished CMT effects on sediment loss. In the previous study on a steep slope (33\%), interrill erosion was comparable between exposed subsoil and a $150 \mathrm{~mm}$ depth of topsoil applied over subsoil with or without seeding [5].

Treatment effects on sediment loss were reflected in variation of runoff loss of TKN in sediment. Runoff loss of sediment TKN was low and similar between ECC and established grass (Table 4). In addition, runoff loss of sediment TKN from ECC was less than two of the four CMT treatments even though TN concentrations within the top-dressed ECC layer were greater than CMT or established grass (Tables 2 and 4). On a steep embankment (33\%), low runoff volume prevented sediment TN loss from top-dressed biosolids and yard waste during a $30 \mathrm{~min}$. simulated rain event despite a doubling of sediment TN concentration [3].

Although ECC prevented loss of sediment TKN similar to established grass, sediment TP loss was greater for ECC than established grass and the lower rate $\left(0.125 \mathrm{~m}^{3} \mathrm{~m}^{-3}\right)$ of CDM in CMT (Table 4). In addition, runoff loss of sediment TP from ECC composed of CDM was greater than all other treatments, including ECC derived from CMB. This result is likely due to the relatively higher TP concentration in the ECC when CDM was used in the compost/woodchip mix (Tables 2 and 4).

3.4. TDP and $\mathrm{NO}_{3}{ }^{-}-\mathrm{N}$ Concentrations in Runoff. Runoff events were analyzed separately to accommodate significant ( $\alpha=0.001$ ) interactions between treatment and rain event for variation of TDP and $\mathrm{NO}_{3}-\mathrm{N}$ concentrations in filtrate 
TABLE 4: Total runoff and the sum of mass loss of runoff sediment and associated total $\mathrm{P}$ and $\mathrm{N}$ over 10 rain events during grass establishment on roadside slope amended with composted dairy manure (CDM) and composted municipal biosolids (CMB). See Table 2 caption for description of treatments.

\begin{tabular}{lcccccccccc}
\hline \multicolumn{2}{l}{ Treatment Compost } & $\begin{array}{c}\text { Rate } \\
\left(\mathrm{m}^{3} \mathrm{~m}^{-3}\right)\end{array}$ & \multicolumn{2}{c}{$\begin{array}{c}\text { Runoff } \\
(\mathrm{mm})\end{array}$} & \multicolumn{2}{c}{$\begin{array}{c}\text { Sediment } \\
\left(\mathrm{g} \mathrm{m}^{-2}\right)\end{array}$} & $\begin{array}{c}\text { Total P } \\
\left(\mathrm{mg} \mathrm{m}^{-2}\right)\end{array}$ & $\begin{array}{c}\text { TKN } \\
\left(\mathrm{mg} \mathrm{m}^{-2}\right)\end{array}$ \\
\hline Control & NA & NA & 156 & $\mathrm{bc}$ & 111 & $\mathrm{~cd}$ & 328 & $\mathrm{c}$ & 115 & $\mathrm{~b}$ \\
CMT & CDM & 0.125 & 194 & $\mathrm{ab}$ & 525 & $\mathrm{~b}$ & 361 & $\mathrm{c}$ & 554 & $\mathrm{ab}$ \\
CMT & $\mathrm{CMB}$ & 0.125 & 178 & $\mathrm{ab}$ & 398 & $\mathrm{~b}$ & 439 & $\mathrm{bc}$ & 1373 & $\mathrm{a}$ \\
CMT & CDM & 0.25 & 206 & $\mathrm{a}$ & 872 & $\mathrm{a}$ & 646 & $\mathrm{~b}$ & 1380 & $\mathrm{a}$ \\
CMT & CMB & 0.25 & 168 & $\mathrm{abc}$ & 469 & $\mathrm{~b}$ & 454 & $\mathrm{bc}$ & 664 & $\mathrm{ab}$ \\
ECC & CDM & 0.50 & 178 & $\mathrm{ab}$ & 44 & $\mathrm{~d}$ & 965 & $\mathrm{a}$ & 60 & $\mathrm{~b}$ \\
ECC & CMB & 0.50 & 137 & $\mathrm{c}$ & 11 & $\mathrm{~d}$ & 681 & $\mathrm{~b}$ & 16 & $\mathrm{~b}$ \\
\hline
\end{tabular}

${ }^{\dagger}$ Different letters in columns represent significant differences using Fisher's LSD means separation test.

TABLE 5: Comparison of runoff concentration of total dissolved P (TDP) among contrasting roadside treatments for selected rain events on an $8.5 \%$ slope. Rain amounts for the respective events were $23,5,18,29$, and $50 \mathrm{~mm}$. See Table 2 caption for description of treatments and compost sources.

\begin{tabular}{|c|c|c|c|c|c|c|c|c|c|c|c|c|}
\hline \multirow{3}{*}{$\begin{array}{l}\text { Treatment } \\
\text { Control }\end{array}$} & \multirow{3}{*}{$\begin{array}{c}\text { Compost } \\
\text { NA }\end{array}$} & \multirow{3}{*}{$\frac{\begin{array}{c}\text { Rate } \\
\left(\mathrm{m}^{3} \mathrm{~m}^{-3}\right)\end{array}}{\mathrm{NA}}$} & \multicolumn{10}{|c|}{ Rain event } \\
\hline & & & \multicolumn{2}{|c|}{$\begin{array}{l}1 \text { (5 Jun) } \\
\left(\mathrm{mg} \mathrm{L}^{-1}\right)\end{array}$} & \multicolumn{2}{|c|}{$\begin{array}{c}3 \text { (14 Jun) } \\
\left(\mathrm{mg} \mathrm{L}^{-1}\right)\end{array}$} & \multicolumn{2}{|c|}{$\begin{array}{c}6(4 \mathrm{Jul}) \\
\left(\mathrm{mg} \mathrm{L}^{-1}\right) \\
\end{array}$} & \multicolumn{2}{|c|}{$\begin{array}{c}8 \text { (11 Aug) } \\
\left(\mathrm{mg} \mathrm{L}^{-1}\right)\end{array}$} & \multicolumn{2}{|c|}{$\begin{array}{c}10 \text { (31 Aug) } \\
\left(\mathrm{mg} \mathrm{L}^{-1}\right)\end{array}$} \\
\hline & & & 1.9 & $\mathrm{~d}$ & 2.2 & $\mathrm{~d}$ & 1.8 & c & 3.2 & $\mathrm{~b}$ & 2.6 & c \\
\hline CMT & CDM & 0.125 & 2.7 & $\mathrm{~d}$ & 3.2 & $\mathrm{~cd}$ & 2.4 & c & 3.4 & $\mathrm{~b}$ & 2.6 & c \\
\hline CMT & $\mathrm{CMB}$ & 0.125 & 2.6 & d & 2.8 & $\mathrm{~d}$ & 2.1 & c & 3.8 & $\mathrm{~b}$ & 3.3 & c \\
\hline CMT & CDM & 0.25 & 5.2 & c & 6.0 & $c$ & 2.8 & c & 3.9 & $\mathrm{~b}$ & 3.3 & c \\
\hline CMT & $\mathrm{CMB}$ & 0.25 & 3.2 & $\mathrm{~cd}$ & 3.4 & $\mathrm{~cd}$ & 2.7 & c & 4.2 & $\mathrm{~b}$ & 3.2 & c \\
\hline ECC & CDM & 0.50 & 17.1 & $\mathrm{a}$ & 17.3 & $\mathrm{a}$ & 11.4 & a & 11.0 & $\mathrm{a}$ & 11.2 & a \\
\hline ECC & $\mathrm{CMB}$ & 0.50 & 9.6 & $\mathrm{~b}$ & 13.0 & $\mathrm{~b}$ & 8.0 & $\mathrm{~b}$ & 11.4 & $\mathrm{a}$ & 8.3 & b \\
\hline
\end{tabular}

${ }^{\dagger}$ Different letters in columns represent significant differences using Fisher's LSD means separation test.

of runoff. Five of the 10 runoff events were selected to illustrate variation of runoff concentrations of TDP and $\mathrm{NO}_{3}{ }^{-}-\mathrm{N}$ among treatments during the period of bluestem establishment (Tables 5 and 6 ). As anticipated from variation of runoff loss of sediment TP among treatments (Table 4), runoff concentrations of TDP were consistently greater for ECC than CMT or the established grass control (Table 5). Similarly, incorporation reduced runoff concentrations of dissolved P compared to top-dressed application of livestock manures $[11,36]$. In contrast, a previous study indicated TDP concentration in runoff from ECC was less or similar to that from CMT during the first two rain events after these CDM-amended treatments were applied and seeded [10].

In the present study, incorporation of $\mathrm{CDM}$ at $0.25 \mathrm{~m}^{3} \mathrm{~m}^{-3}$ with soil did increase TDP concentrations in runoff compared to established grass during rain events 1 and 3 (Table 5). In addition, CDM contributed to greater TDP concentrations in runoff than the CMB mixed with wood chips in ECC on four of the five selected rain events. Yet TDP concentrations in runoff were similar among three of the four CMT treatments during events 1 and 3. In addition, runoff concentrations of TDP were similar among all four CMT treatments and the grass control as bluestem establishment progressed during rain events 6 through 10 (Table 5).

After the initial rain event, filtrate concentration of $\mathrm{NO}_{3}{ }^{-}-\mathrm{N}$ declined and remained low and similar between $\mathrm{CMT}$ and the established grass control over the remaining events (Table 6). Comparable results were observed previously using two soil types and $\mathrm{CDM}$ to apply CMT amendments at $0.25 \mathrm{~m}^{3} \mathrm{~m}^{-3}$ [10]. In the previous and present study, runoff $\mathrm{NO}_{3}-\mathrm{N}$ concentration was greater for CMT amended with CDM or CMB at $0.25 \mathrm{~m}^{3} \mathrm{~m}^{-3}$ of soil than established grass during the initial rain event (Table 6). After the first rain event, $\mathrm{NO}_{3}{ }^{-}-\mathrm{N}$ concentrations in runoff were similar $\left(0.57 \mathrm{mg} \mathrm{L}^{-1}\right)$ to those reported for grassland soils mixed with poultry litter [28]. Runoff concentrations of $\mathrm{NO}_{3}-\mathrm{N}$ were greater for ECC than CMT on rain events 8 and 10, but runoff concentrations were well below the EPA drinking water standard [37]. Both bluestem uptake and slow mineralization from compost could have minimized $\mathrm{NO}_{3}$ $\mathrm{N}$ concentrations in amended soil and runoff [33]. Glanville et al. [3] similarly reported low $\mathrm{NO}_{3}{ }^{-}-\mathrm{N}$ concentrations in runoff $\left(0.2 \mathrm{mg} \mathrm{L}^{-1}\right)$ from a surface application of biosolids mixed with yard waste on a roadside embankment. 
TABLE 6: Comparison of runoff concentration of $\mathrm{NO}_{3}-\mathrm{N}$ among contrasting roadside treatments for selected rain events on an $8.5 \%$ slope. Rain amounts for the respective events were 23, 5, 18, 29, and $50 \mathrm{~mm}$. See Table 2 caption for description of treatments and compost sources.

\begin{tabular}{|c|c|c|c|c|c|c|c|c|c|c|c|c|}
\hline \multirow{3}{*}{$\begin{array}{l}\text { Treatment } \\
\text { Control }\end{array}$} & \multirow{3}{*}{$\begin{array}{c}\text { Compost } \\
\text { NA }\end{array}$} & \multirow{3}{*}{$\frac{\begin{array}{c}\text { Rate } \\
\left(\mathrm{m}^{3} \mathrm{~m}^{-3}\right)\end{array}}{\text { NA }}$} & \multirow{2}{*}{\multicolumn{6}{|c|}{$\begin{array}{c}\text { Rain event } \\
6(4 \mathrm{Jul}) \\
\left(\mathrm{mg} \mathrm{L}^{-1}\right)\end{array}$}} & \multirow{2}{*}{\multicolumn{2}{|c|}{$\begin{array}{c}8 \text { (11 Aug) } \\
\left(\mathrm{mg} \mathrm{L}^{-1}\right)\end{array}$}} & \multirow{2}{*}{\multicolumn{2}{|c|}{$\begin{array}{c}10 \text { (31 Aug) } \\
\left(\mathrm{mg} \mathrm{L}^{-1}\right)\end{array}$}} \\
\hline & & & & & & & & & & & & \\
\hline & & & 0.59 & $\mathrm{~d}$ & 0.22 & $\mathrm{a}$ & 0.25 & $\mathrm{a}$ & 0.55 & $\mathrm{~b}$ & 0.25 & bc \\
\hline CMT & $\mathrm{CDM}$ & 0.125 & 1.20 & bcd & 0.48 & $\mathrm{a}$ & 0.51 & $\mathrm{a}$ & 0.64 & $\mathrm{~b}$ & 0.23 & $c$ \\
\hline CMT & $\mathrm{CMB}$ & 0.125 & 1.10 & $\mathrm{~cd}$ & 0.32 & $\mathrm{a}$ & 0.17 & $\mathrm{a}$ & 0.41 & $\mathrm{~b}$ & 0.21 & $c$ \\
\hline $\mathrm{CMT}$ & $\mathrm{CDM}$ & 0.25 & 2.38 & a & 0.69 & $\mathrm{a}$ & 0.40 & $\mathrm{a}$ & 0.41 & $\mathrm{~b}$ & 0.23 & c \\
\hline CMT & CMB & 0.25 & 1.65 & $\mathrm{abc}$ & 0.47 & $\mathrm{a}$ & 0.25 & $\mathrm{a}$ & 0.40 & $\mathrm{~b}$ & 0.21 & c \\
\hline ECC & $\mathrm{CDM}$ & 0.50 & 1.41 & bcd & 0.28 & $\mathrm{a}$ & 0.46 & $a$ & 1.15 & $\mathrm{a}$ & 0.30 & $a b$ \\
\hline ECC & $\mathrm{CMB}$ & 0.50 & 2.01 & $\mathrm{ab}$ & 0.45 & $\mathrm{a}$ & 0.45 & $\mathrm{a}$ & 1.42 & $\mathrm{a}$ & 0.34 & $\mathrm{a}$ \\
\hline
\end{tabular}

${ }^{\dagger}$ Different letters in columns represent significant differences using Fisher's LSD means separation test.

TABLE 7: Mass runoff loss of total dissolved P (TDP), dissolved reactive P (DRP), $\mathrm{NO}^{3}-\mathrm{N}$, and dissolved total Kjeldahl N (TKN) during grass establishment on roadside soils amended with composted dairy manure (CDM) and composted municipal biosolids (CMB) over 10 natural rainfall events. See Table 2 caption for description of treatments.

\begin{tabular}{|c|c|c|c|c|c|c|c|c|c|c|}
\hline \multirow{2}{*}{$\begin{array}{l}\text { Treatment } \\
\text { Control }\end{array}$} & \multirow{2}{*}{$\begin{array}{c}\text { Compost } \\
\text { NA }\end{array}$} & \multirow{2}{*}{$\begin{array}{c}\begin{array}{c}\text { Rate } \\
\left(\mathrm{m}^{3} \mathrm{~m}^{-3}\right)\end{array} \\
\mathrm{NA}\end{array}$} & \multicolumn{2}{|c|}{$\begin{array}{c}\text { TDP } \\
\left(\mathrm{mg} \mathrm{m}^{-2}\right)\end{array}$} & \multicolumn{2}{|c|}{$\begin{array}{c}\mathrm{DRP} \\
\left(\mathrm{mg} \mathrm{m}^{-2}\right)\end{array}$} & \multicolumn{2}{|c|}{$\begin{array}{l}\mathrm{NO}_{3}{ }^{-}-\mathrm{N} \\
\left(\mathrm{mg} \mathrm{m}^{-2}\right)\end{array}$} & \multicolumn{2}{|c|}{$\begin{array}{c}\mathrm{TKN} \\
\left(\mathrm{mg} \mathrm{m}^{-2}\right)\end{array}$} \\
\hline & & & 301 & $\mathrm{~d}$ & 165 & $\mathrm{e}$ & 45 & $\mathrm{~b}$ & 775 & $\mathrm{~b}$ \\
\hline CMT & CDM & 0.125 & 450 & $\mathrm{~cd}$ & 303 & $\mathrm{~d}$ & 86 & $\mathrm{~b}$ & 786 & $\mathrm{~b}$ \\
\hline CMT & $\mathrm{CMB}$ & 0.125 & 428 & $\mathrm{~cd}$ & 272 & de & 59 & $\mathrm{~b}$ & 815 & $\mathrm{~b}$ \\
\hline CMT & $\mathrm{CDM}$ & 0.25 & 637 & c & 450 & $c$ & 140 & $\mathrm{a}$ & 1025 & $\mathrm{~b}$ \\
\hline CMT & CMB & 0.25 & 440 & $\mathrm{~cd}$ & 308 & $\mathrm{~d}$ & 78 & $\mathrm{~b}$ & 770 & $\mathrm{~b}$ \\
\hline ECC & $\mathrm{CDM}$ & 0.50 & 1845 & $\mathrm{a}$ & 1321 & $\mathrm{a}$ & 75 & $\mathrm{~b}$ & 1756 & $\mathrm{a}$ \\
\hline ECC & $\mathrm{CMB}$ & 0.50 & 1050 & $\mathrm{~b}$ & 841 & b & 71 & $\mathrm{~b}$ & 1549 & $\mathrm{a}$ \\
\hline
\end{tabular}

${ }^{\dagger}$ Different letters in columns represent significant differences using Fisher's LSD means separation test.

3.5. Nutrient Losses. Variation of cumulative runoff loss of TDP among treatments over the 10 rainfall events reflected variation of runoff concentrations of TDP for events 1 and 3 (Tables 5 and 7). Similar to benefits reported for agricultural soils, incorporating $\mathrm{CDM}$ or $\mathrm{CMB}$ into the 0 to $50 \mathrm{~mm}$ soil depth (CMT) reduced TDP losses in runoff compared to top-dressed ECC [17]. Except for CDM incorporated at $0.25 \mathrm{~m}^{3} \mathrm{~m}^{-3}$ soil, CMT limited cumulative runoff loss of TDP during grass establishment as effectively as the established grass control (Table 7). In contrast, cumulative mass loss of TDP during grass establishment was greater for ECC than for CMT or the established grass control. In addition, cumulative TDP loss from ECC was greater for CDM than for $\mathrm{CMB}$ even though TP concentration was nearly 3 times greater in $\mathrm{CMB}$ than $\mathrm{CDM}$ incorporated with soil (Tables 2 and 7). Greater cumulative TDP loss from ECC amended with CDM did reflect the greater total runoff depth over 10 rainfall events for CDM-compared to CMBamended ECC (Tables 4 and 7). Glanville et al. [3] reported runoff volume effects on runoff loss of soluble and adsorbed $\mathrm{P}$ forms were even greater between top-dressed biosolids and excavated soil during a simulated $30 \mathrm{~min}$ storm. Runoff loss of soluble plus adsorbed $\mathrm{P}$ was 8 times greater for exposed soil than for the top-dressed biosolids layer. Conversely, respective concentrations were 81 and 20 times greater for soluble $\mathrm{P}\left(3.1 \mathrm{mg} \mathrm{L}^{-1}\right)$ and sediment $\mathrm{P}\left(17.3 \mathrm{~g} \mathrm{~L}^{-1}\right)$ in runoff from top-dressed biosolids than from exposed soil [3].

The dissolved reactive fraction of P (DRP) contributed $64 \%$ or more of the runoff loss of TDP over the 10 runoff events during establishment of the seeded bluestem (Table 7). Similarly, DRP accounted for $64 \%$ of total P loss in simulated runoff from soils amended with manure sources of $P$ [11]. For both simulated and natural rainfall in the previous and present study, runoff loss of DRP was lower for incorporated compared to top-dressed raw manure, CDM, or CMB (Table 5). In addition, incorporation of the lower rate of CMB $\left(0.125 \mathrm{~m}^{3} \mathrm{~m}^{-3}\right)$ reduced DRP runoff loss to amounts comparable to the grass control. Similar to TDP losses in runoff from ECC over 10 runoff events, greater runoff loss of DRP from CDM than from CMB was attributed to differences in cumulative runoff depth and WEP concentration (Tables 2 and 7). Importantly, DRP is the fraction of $\mathrm{P}$ in surface water considered most available to aquatic plants and could contribute to accelerated eutrophication at concentrations orders of magnitude less than observed in this study [8].

High runoff volume contributed to relatively high runoff loss of $\mathrm{NO}_{3}-\mathrm{N}$ from CMT amended with $\mathrm{CDM}$ at $0.25 \mathrm{~m}^{3} \mathrm{~m}^{-3}$ of soil, but losses from ECC and other CMT treatments reflected low $\mathrm{NO}_{3}-\mathrm{N}$ concentrations in runoff (Tables 6 and 7). Although ECC prevented sediment and 
associated TKN loss similar to the grass control, ECC was a major nonpoint source of dissolved TKN. In contrast to treatment differences in runoff loss of sediment TKN, loss of dissolved TKN was greater for ECC than for CMT or established perennial grass over the 10 runoff events (Tables 4 and 7). Conversely, runoff loss of dissolved TKN from CMT was comparable to the established grass control (Table 7). The ECC did not lower runoff volume sufficiently to reduce dissolved TKN in runoff compared to CMT or the grass control during the 10 natural rainfall events in the present study. In contrast, Glanville et al. [3] reported lower runoff volume during a 30 min simulated rain reduced total $\mathrm{N}$ in runoff from top-dressed biosolid and yard waste to $0.1 \%$ of that from the exposed subsoil.

3.6. Relationship between Soil and Runoff P. Similar runoff depths among five of the seven treatments indicated variation of nutrient concentrations in soil, and runoff contributed a major portion of variation of mass loss of nutrients among treatments $[13,14,17,18,35]$. Regression analysis was used to relate variation of soil $\mathrm{P}$ concentration to variation of $\mathrm{P}$ runoff losses among roadside amendments and between compost sources. Relationships between soil and runoff $\mathrm{P}$, though soil specific, enable evaluation of ECC and CMT effects on water quality for both site and watershed scales $[14,15,38,39]$. In the present study, the sum of TDP and sediment $\mathrm{P}$ losses for each treatment was accumulated over 10 rainfall events and related to $\mathrm{P}$ concentrations in soil sampled after the final event. Linear relationships were observed between mass runoff losses of TP for the control, CMT, and ECC treatments of each compost source and mean WEP, STP, and TP in the 0 to $50 \mathrm{~mm}$ soil depth (Figures 1,2 , and 3). Slopes of regression relationships between soil WEP and TP runoff loss were similar between CDM and $\mathrm{CMB}$ (Figure 1). In contrast, slopes of relationships between STP (Figure 2) or soil TP (Figure 3) and runoff $\mathrm{TP}$ varied markedly between $\mathrm{CDM}$ and $\mathrm{CMB}$ sources used to amend soil. Although the volume-based rates of $\mathrm{CMB}$ increased soil total P and STP concentrations compared to respective CDM rates, soil WEP concentrations were greater for CDM-amended treatments. Similar to previous comparisons among varied sources of livestock manure [16], WEP was the most effective environmental indicator of nonpoint-source runoff loss of $\mathrm{P}$ from the roadside amendments.

\section{Conclusions}

Runoff and nutrient losses during grass establishment on an excavated slope revealed similarities and differences between ECC and CMT treatments. The ECC enhanced early establishment of bluestem compared to CMT, but both ECC and CMT yielded biomass comparable to or greater than established grass after $98 \mathrm{~d}$. Although ECC more consistently limited runoff loss of sediment and associated TKN, loss of dissolved TKN was greater for ECC than CMT or established grass. Incorporation of CDM or CMB in CMT reduced loss of TDP and sediment and dissolved TKN to levels comparable to established grass. However, the interaction between the

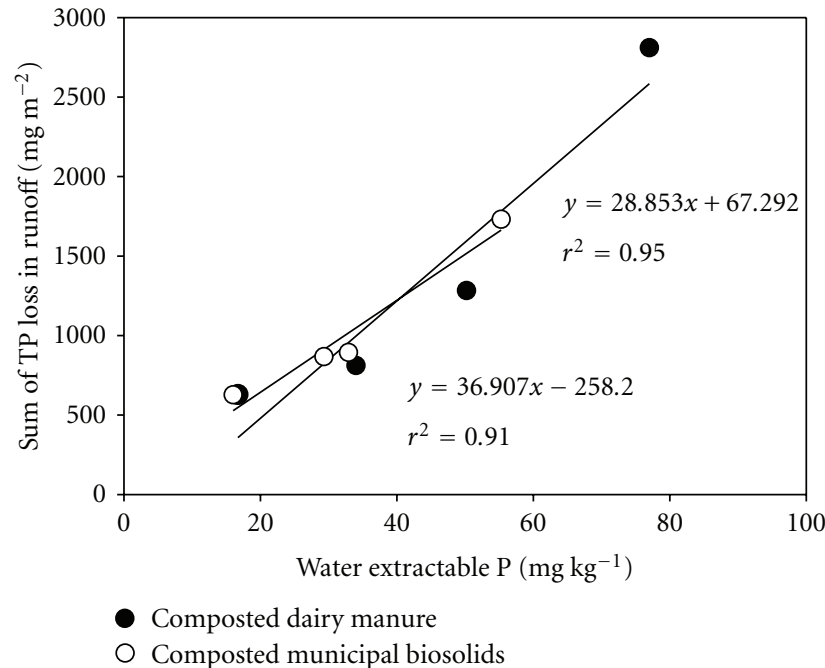

Figure 1: The mean sums of total P (total P) loss in runoff water over 10 rain events compared to mean water-extractable $\mathrm{P}$ concentration in 0 to $50 \mathrm{~mm}$ depth of contrasting roadside treatments on an $8.5 \%$ slope. Soil was sampled from established perennial grass, compost-manufactured topsoil, and erosion-control compost treatments after the final rain event.

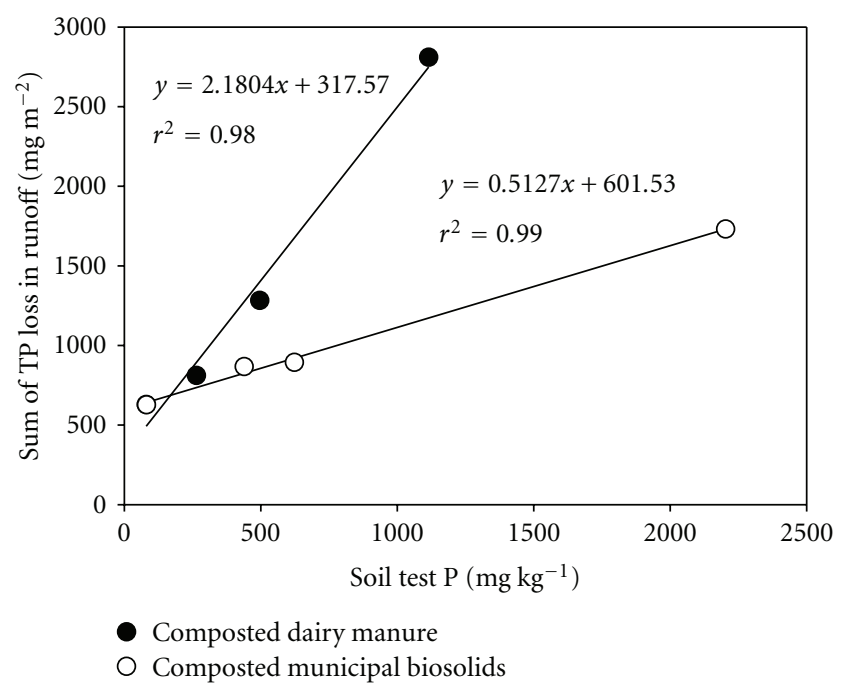

Figure 2: Relationship between the mean sum of total P (TP) loss in runoff water over 10 rain events and mean soil-test $\mathrm{P}$ within 0 to $5 \mathrm{~mm}$ depth of contrasting roadside treatments on an $8.5 \%$ slope. Soil was sampled from established perennial grass, compostmanufactured topsoil, and erosion-control compost after the final rain event.

compost products used and soil properties affecting nutrient losses in runoff is likely influenced by the soil type used in this study. Variation of nutrient concentration in amended depths of ECC and CMT and in runoff contributed to a major portion of variation of $\mathrm{P}$ loss in runoff. Variation of TP loss in runoff was directly related to variation of WEP, STP, and TP within the 0 to $5 \mathrm{~cm}$ depth of treatments. For the CDM and CMB sources used in ECC and CMT, 


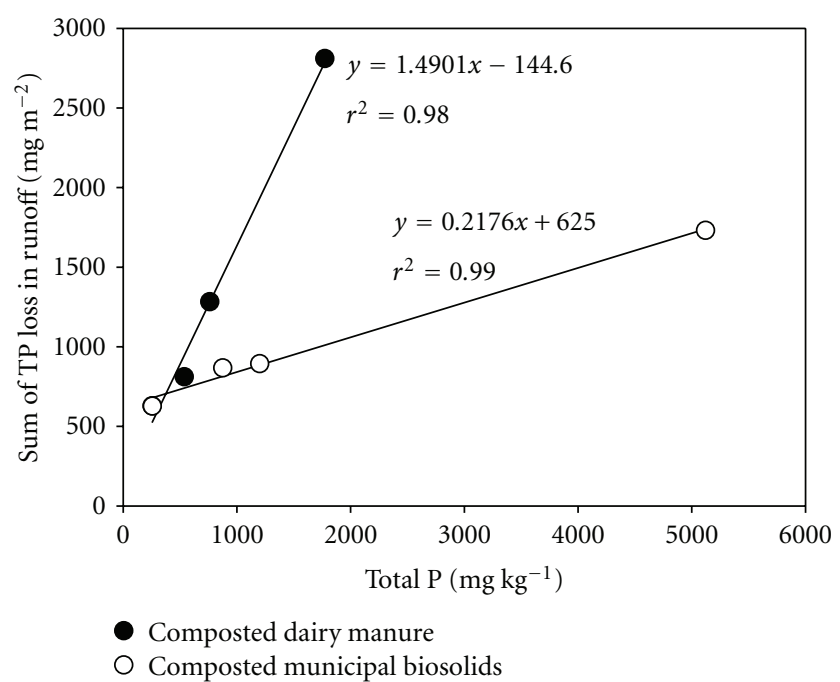

Figure 3: The mean sums of total P (TP) loss in runoff water over 10 rain events compared to mean total $\mathrm{P}$ concentration in 0 to $50 \mathrm{~mm}$ depth of contrasting roadside treatments on an $8.5 \%$ slope. Soil was sampled from established perennial grass, compost-manufactured topsoil, and erosion-control compost treatments after the final rain event.

variation of WEP within amended soil depths was the best indicator of variation of TP runoff loss. Compost needs to be analyzed and rates and application method managed to keep WEP and other water-soluble nutrient concentrations in CMT at levels that prevent nonpoint-source losses in runoff. Additional research is needed to quantify long-term water quality impacts of CMT and ECC composed of CDM or $\mathrm{CMB}$ and the interaction differing soil types may have on those impacts.

\section{Abbreviations}

ECC: Erosion control compost

CMT: Compost manufactured topsoil

$\mathrm{N}$ : Nitrogen

P: $\quad$ Phosphorus

CDM: Composted dairy manure

CMB: Composted municipal biosolids

TKN: Total Kjeldahl N

TDP: Total dissolved phosphorus

WEP: Water extractable phosphorus

TP: $\quad$ Total phosphorus

TxDOT: Texas Department of Transportation.

\section{References}

[1] M. E. Barrett, J. F. Malina, R. J. Charbeneau, and G. H. Ward, "Water quality and quantity impacts of highway construction and operation: summary and conclusions," Tech. Rep. CRWR 266, Center for Research in Water Resources, Bureau of Engineering Research, The University of Texas at Austin, 1995.

[2] S. R. Benik, B. N. Wilson, D. D. Biesboer, B. Hansen, and D. Stenlund, "Performance of erosion control products on a highway embankment," Transactions of the American Society of Agricultural Engineers, vol. 46, no. 4, pp. 1113-1119, 2003.

[3] T. D. Glanville, R. A. Persyn, T. L. Richard, J. M. Laflen, and P. M. Dixon, "Environmental effects of applying composted organics to new highway embankments: part 2. Water quality," Transactions of the American Society of Agricultural Engineers, vol. 47, no. 2, pp. 471-478, 2004.

[4] D. Mitchell, "State transportation departments expand compost use," Biocycle, vol. 38, pp. 75-80, 1997.

[5] R. A. Persyn, T. D. Glanville, T. L. Richard, J. M. Laflen, and P. M. Dixon, "Environmental effects of applying composted organics to new highway embankments: part 1. Interrill runoff and erosion," Transactions of the American Society of Agricultural Engineers, vol. 47, no. 2, pp. 463-469, 2004.

[6] R. J. Black, G. L. Miller, and G. Kidder, "Compost utilization by state departments of transportation in the United States," Fact Sheet ENH-125, Environmental Horticulture Department, Florida Cooperative Extension Service, University of Florida, 1998.

[7] Texas Department of Transportation, "Item 161, Compost," 1993, ftp://ftp.dot.state.tx.us/pub/txdot-info/cmd/cserve/ specs/2004/standard/s161.pdf.

[8] S. R. Carpenter, N. F. Caraco, D. L. Correll, R. W. Howarth, A. N. Sharpley, and V. H. Smith, "Nonpoint pollution of surface waters with phosphorus and nitrogen," Ecological Applications, vol. 8, no. 3, pp. 559-568, 1998.

[9] T. Barkley, "Erosion control with recycled materials," Public Roads, vol. 67, no. 5, 2004, http://www.fhwa.dot.gov/publications/publicroads/04mar/03.cfm.

[10] N. E. Hansen, D. M. Vietor, C. L. Munster, R. H. White, and T. L. Provin, "Runoff water quality from constructed roadside soils receiving large volume-based compost applications," Transactions of the American Society of Agricultural and Biological Engineers, vol. 52, no. 3, pp. 793-800, 2009.

[11] P. J. A. Kleinman, A. N. Sharpley, B. G. Moyer, and G. F. Elwinger, "Effect of mineral and manure phosphorus sources on runoff phosphorus," Journal of Environmental Quality, vol. 31, no. 6, pp. 2026-2033, 2002.

[12] R. O. Maguire, J. T. Sims, S. K. Dentel, F. J. Coale, and J. T. Mah, "Relationships between biosolids treatment process and soil phosphorus availability," Journal of Environmental Quality, vol. 30, no. 3, pp. 1023-1033, 2001.

[13] P. J. A. Kleinman, A. N. Sharpley, T. L. Veith, R. O. Maguire, and P. A. Vadas, "Evaluation of phosphorus transport in surface runoff from packed soil boxes," Journal of Environmental Quality, vol. 33, no. 4, pp. 1413-1423, 2004.

[14] P. D. Schroeder, D. E. Radcliffe, M. L. Cabrera, and C. D. Belew, "Relationship between soil test phosphorus and phosphorus in runoff: effects of soil series variability," Journal of Environmental Quality, vol. 33, no. 4, pp. 1452-1463, 2004.

[15] P. A. Vadas, P. J. A. Kleinman, A. N. Sharpley, and B. L. Turner, "Relating soil phosphorus to dissolved phosphorus in runoff: a single extraction coefficient for water quality modeling," Journal of Environmental Quality, vol. 34, no. 2, pp. 572-580, 2005.

[16] A. Sharpley and B. Moyer, "Phosphorus forms in manure and compost and their release during simulated rainfall," Journal of Environmental Quality, vol. 29, no. 5, pp. 1462-1469, 2000.

[17] D. D. Tarkalson and R. L. Mikkelsen, "Runoff phosphorus losses as related to phosphorus source, application method, and application rate on a Piedmont soil," Journal of Environmental Quality, vol. 33, no. 4, pp. 1424-1430, 2004.

[18] D. M. Vietor, T. L. Provin, R. H. White, and C. L. Munster, "Runoff losses of phosphorus and nitrogen imported in sod 
or composted manure for turf establishment," Journal of Environmental Quality, vol. 33, no. 1, pp. 358-366, 2004.

[19] T. W. Andraski, L. G. Bundy, and K. C. Kilian, "Manure history and long-term tillage effects on soil properties and phosphorus losses in runoff," Journal of Environmental Quality, vol. 32, no. 5, pp. 1782-1789, 2003.

[20] J. E. Gaudreau, D. M. Vietor, R. H. White, T. L. Provin, and C. L. Munster, "Response of turf and quality of water runoff to manure and fertilizer," Journal of Environmental Quality, vol. 31, no. 4, pp. 1316-1322, 2002.

[21] J. A. Parkinson and S. E. Allen, "A wet oxidation procedure for determination of nitrogen and mineral nutrients in biological material," Communications in Soil Science and Plant Analysis, vol. 6, no. 1, pp. 1-11, 1975.

[22] P. M. Haygarth and A. N. Sharpley, "Terminology for phosphorus transfer," Journal of Environmental Quality, vol. 29, no. 1, pp. $10-15,2000$.

[23] R. A. Dorich and D. W. Nelson, "Direct colorometric measurement of ammonium in potassium chloride extracts of soil," Soil Science Society of America Journal, vol. 47, no. 4, pp. 833836, 1983.

[24] R. A. Isaac and J. B. Jones Jr., "Auto-analysis of soil and plant tissure extracts," in Proceedings of the Technicon Congress on Advances in Automated Analysis, pp. 57-64, Technicon, Tarrytown, NY, USA, 1970.

[25] R. A. Dorich and D. W. Nelson, "Evaluation of manual cadmium reduction methods for determination of nitrate in potassium chloride extracts of soils," Soil Science Society of America Journal, vol. 48, no. 1, pp. 72-75, 1984.

[26] E. M. D’Angelo, M. V. Vandiviere, W. O. Thom, and F. Sikora, "Estimating soil phosphorus requirements and limits from oxalate extract data," Journal of Environmental Quality, vol. 32, no. 3, pp. 1082-1088, 2003.

[27] F. M. Hons, L. A. Larson-Vollmer, and M. A. Locke, " $\mathrm{NH}_{4} \mathrm{OAc}$ EDTA-extractable phosphorus as a soil test procedure," Soil Science, vol. 149, no. 5, pp. 249-256, 1990.

[28] D. H. Pote, W. L. Kingery, G. E. Aiken, F. X. Han, P. A. Moore Jr., and K. Buddington, "Water-quality effects of incorporating poultry litter into perennial grassland soils," Journal of Environmental Quality, vol. 32, no. 6, pp. 2392-2398, 2003.

[29] D. G. Kleinbaum and L. L. Kupper, Applied Regression Analysis and Other Multivariate Methods, Duxbury Press, North Scituate, Mass, USA, 1978.

[30] G. Eftoda and D. McCartney, "Determining the critical bulking agent requirement for municipal biosolids composting," Compost Science and Utilization, vol. 12, no. 3, pp. 208-218, 2004.

[31] Texas AgriLife Extension Soil, Water, and Forage Testing Laboratory, "Sodgrass production phosphorus recommendation," 2000, http://soiltesting.tamu.edu/files/soilrecs/p80.pdf.

[32] A. N. Sharpley, P. J. A. Kleinman, and R. W. Mcdowell, "Phosphorus loss from land to water: integrating agricultural and environmental management," Plant and Soil, vol. 237, no. 2, pp. 287-307, 2001.

[33] J. T. Sims, "Nitrogen mineralization and elemental availability in soils amended with cocomposted sewage sludge," Journal of Environmental Quality, vol. 19, no. 4, pp. 669-675, 1990.

[34] R. W. Schnell, D. M. Vietor, C. L. Munster, R. H. White, and T. L. Provin, "Effects of composted biosolids and nitrogen on turfgrass establishment, sod properties, and nutrient export at harvest," HortScience, vol. 44, no. 6, pp. 1746-1750, 2009.

[35] M. C. Pautler and J. T. Sims, "Relationships between soil test phosphorus, soluble phosphorus, and phosphorus saturation in Delaware soils," Soil Science Society of America Journal, vol. 64, no. 2, pp. 765-773, 2000.

[36] A. N. Sharpley, "Depth of surface soil-runoff interaction as affected by rainfall, soil slope, and management," Soil Science Society of America Journal, vol. 49, no. 4, pp. 1010-1015, 1985.

[37] EPA, "Water quality criteria for water," Office of Water, U.S. Environmental Protection Agency, Washington, DC, USA, 1986.

[38] A. N. Sharpley, "Dependence of runoff phosphorus on extractable soil phosphorus," Journal of Environmental Quality, vol. 24, no. 5, pp. 920-926, 1995.

[39] J. T. Sims, A. C. Edwards, O. F. Schoumans, and R. R. Simard, "Integrating soil phosphorus testing into environmentally based agricultural management practices," Journal of Environmental Quality, vol. 29, no. 1, pp. 60-71, 2000. 

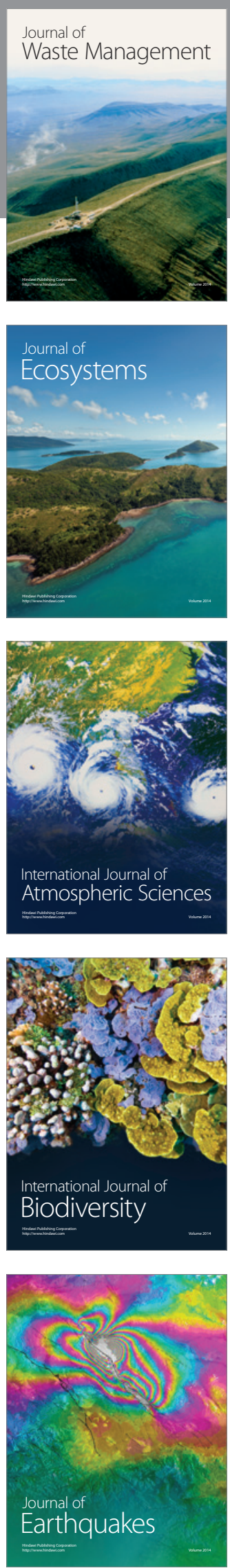
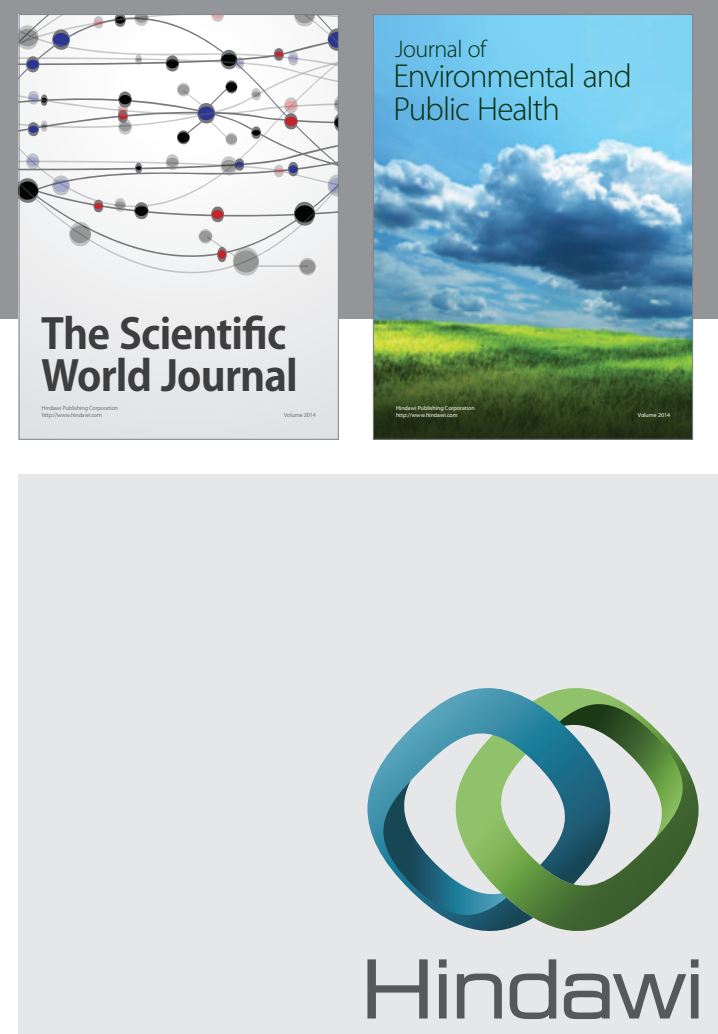

Submit your manuscripts at

http://www.hindawi.com
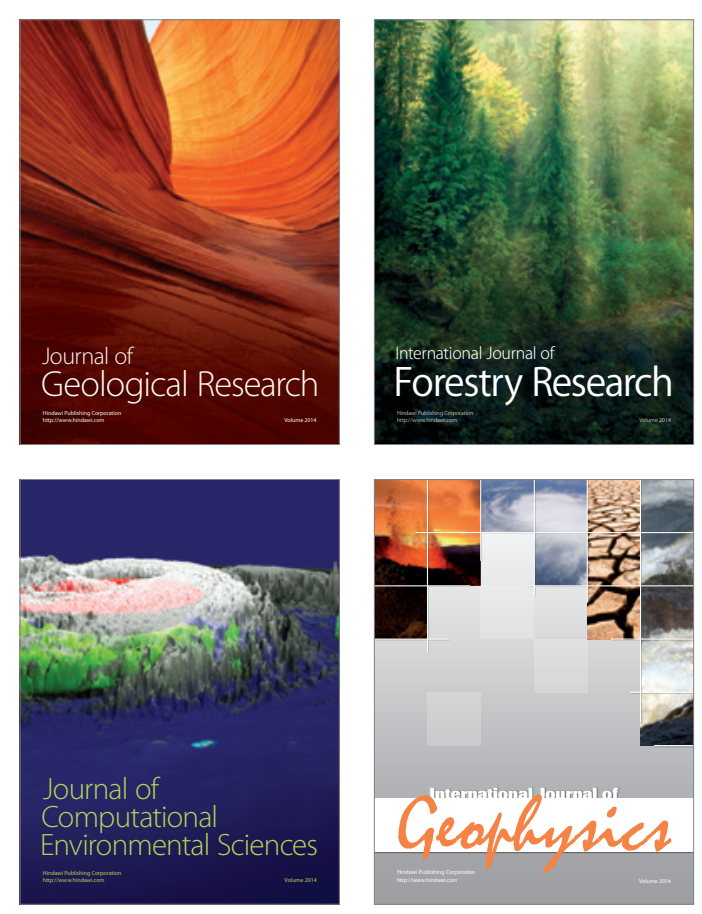
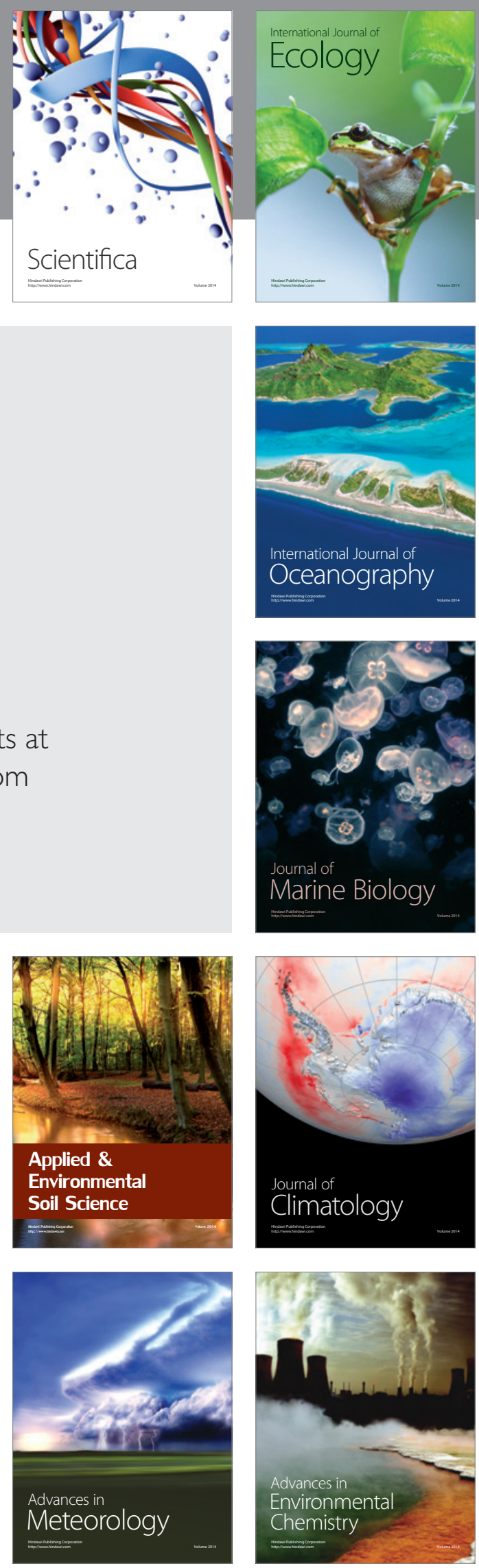